Z Badań nad Książką i Księgozbiorami Historycznymi 2019. T. specjalny: Dla Niepodległej The Studies into the History of the Book and Book Collections 2019. Special issue: For an Independent Poland

\title{
Jan Olaszek
}

Polish Academy of Sciences in Warsaw

Jan.Olaszek@ipn.gov.p1

ORCID 0000-0002-7700-3256

\section{The $2^{\text {nd }}$ Polish Republic in underground publications in the Polish People's Republic}

\begin{abstract}
The article outlines the achievements of an independent publishing movement in the, ruled by communist's, Polish People's Republic concerning the pre-war Second Polish Republic. It was advisable that the characters and themes from the history of pre-war Poland were popular among underground publishers and that they were overlooked. At the same time, the article presents a dispute between supporters of the idealized vision of the Second Polish Republic and its critics.
\end{abstract}

Key words: $2^{\text {nd }}$ Polish Republic - Polish People's Republic - democratic opposition independent publishing movement - Józef Piłsudski - Roman Dmowski.

„Z Badań nad Książką i Księgozbiorami Historycznymi” - Udział zagranicznych recenzentów w ocenie publikacji; Stworzenie anglojęzycznej wersji wydawniczej publikacji; Digitalizacja tomów archiwalnych rocznika w celu zapewnienia otwartego dostępu do nich przez Internet oraz wdrożenie i utrzymanie cyfrowej platformy redakcyjnej - zadanie finansowane w ramach umowy nr 653/P-DUN/2019 ze środków Ministra Nauki i Szkolnictwa Wyższego przeznaczonych na działalność upowszechniającą naukę. 
There had been a fight for legitimization between democratic opposition and communist authorities since the second half of the 70s. in the Polish People's Republic (Polska Rzeczpospolita Ludowa, PRL). The modern history was specifically used as a weapon in that fight ${ }^{1}$. Historical topics were often discussed in books and journals published beyond censorship, which were very popular among the readers ${ }^{2}$. "The modern history of Poland reigns in distribution: in serious books, memories, diaries and personal relations", wrote Joanna Szczęsna, an underground journalist in 1987 in the text Rajd po skrzynkach, published in "Tygodnik Mazowsze" (Mazowia Weekly), a kind of reportage or report from distribution locations of uncensored publications ${ }^{3}$. It is easy to figure out that the greatest interest was awakened by the threads "touchy" from the communist authority's point of view, which were omitted or falsified in official publications, concerning mostly the Soviet crimes on the Poles during World War II and after, as well as the history of Poland ruled by the communist in general.

As the results of a survey realized back in the eighties of the $20^{\text {th }}$ century on the sample of several dozen distributors of independent publications, preserved in the Archive of the KARTA Center reveal, the readers' interest in the history of Poland before 1939 was significantly lower ${ }^{4}$. Why the interwar period was less popular than newer historical topics? Despite an obvious reason that it awoke fewer emotions along with a time flow one more question should be considered. When an independent publishing was established in Poland, important and reliable books concerning the $2^{\text {nd }}$ Polish Republic had been published for some time. Even Andrzej Garlicki or Tomasz and Daria Nałęcz themselves wrote in a very different way about Józef Piłsudski, a person which had been demonized before in PRL. At the same time writing on this topic in the underground publications undoubtedly stimulated interest in this period, the history was alive, and still was a subject of dispute.

The goal of this article is precisely to sketch an output of the independent publishing movement concerning the history of the $2^{\text {nd }}$ Polish Republic in PRL. I will try to show which individuals and topics from the pre-war Poland history

A. Paczkowski, Przeszłość jako obszar starcia o legitymizacje - manewry obronne PZPR w okresie finalnego kryzysu systemu, [in:] Meandry legitymizacji. Studia i analizy, ed. by I. Pańków, Warszawa 2011, p. 25; M. Zaremba, Komunizm, legitymizacja, nacjonalizm. Nacjonalistyczna legitymizacja władzy komunistycznej w Polsce, Warszawa 2005, p. 383.

2 N. Jarska, J. Olaszek, Co czytała opozycja? Książi drugiego obiegu jako wyraz tożsamości politycznej, ideowej i kulturowej opozycji w PRL (1976-1989), [in:] Drugi obieg w PRL na tle samizdatu w państwach bloku sowieckiego po 1956 roku, ed. by P. Gasztold-Seń, N. Jarska, J. Olaszek, Warszawa 2016, p. 150.

3 J. Klincz [J. Szczęsna], Rajd po skrzynkach, "Tygodnik Mazowsze" 29 VII 1987, no 218, p. 1,3 .

4 The Archive of the KARTA Center, the Opposition Archive, sign. IV/187.3, M. Strzeszewski, Kolporterzy o problemach niezależnego ruchu wydawniczego, typewriting, p. 4. 
received particular popularity among underground publishers and readers. There were either reprints of works published in exile or in the country just before the war or those written especially for the underground circulation among publications concerning the $2^{\text {nd }}$ Polish Republic. The latter, from the point of view of this analysis, will be the most interesting, as they will present an attitude of underground authors to this period, although the reprints themselves also should be considered. This sketch does not aspire to complete the topic of the $2^{\text {nd }}$ Polish Republic being discussed in publications beyond censorship in PRL. Therefore, I will necessarily base on a subjective selection of names, topics, titles and texts to be referred to in the text below, otherwise, the sketch would become a bibliography. Therefore I will rather indicate some traces and features characteristic for underground publications concerning the interwar period than prepare a complete description. I decided to give particular attention to two figures symbolic for the $2^{\text {nd }} \mathrm{PR}-\mathrm{J}$. Piłsudski and Roman Dmowski, and two traditions related to them, which - as it seems - consolidate a wide range of problems related to the interwar Poland: its origins, ways of reaching an independent state, the problem of democracy and attitude towards national minorities.

Among 32 texts the most often published underground there are several titles concerning $2^{\text {nd }}$ PR: a short story of Stefan Żeromski Na probostwie w Wyszkow$i e$, interwoven with the history of the war of 1920 (20 underground editions) $)^{5}$, Historia dwudziestolecia (1918-1939) (History of interwar period) by Pawel Zaremba (14 editions, excluding brochures with fragments of the book) ${ }^{6}$, and the book of Mieczysław Zułowski Wojna z Rosja o niepodległość 1918-1920 (The war of independence with Russia 1918-1920; 13 editions) ${ }^{7}$. The interwar period was also discussed in popular, often reissued underground syntheses of the modern history of Poland by Wojciech Roszkowski and Władysław Pobóg-Malinowski ${ }^{8}$. Two works are worth mentioning among publications describing the interwar history of Poland in a more complete way: the first part of the Jan Karski's book Wielkie mocarstwa a Polska (The Great Powers and Poland), concerning the period between the Versailles Treaty and the World War II outbreak, and the text by Norman Davies published as a brochure

5 First edition: S. Żeromski, Na probostwie w Wyszkowie, foreword by J.J. Lipski, Warszawa: Niezależna Oficyna Wydawnicza, 1978. I referred to Ksiażki polskie podziemne (1976-1989) database available at the National Library of Poland webslite.

6 Several first editions in 1981.

7 First edition: M. Zułowski, Wojna z Rosja o niepodległość 1918-1920, Warszawa: Wydawnictwo Polskie, 1978.

8 In some editions they were divided into parts according to chronology, therefore actually the whole was published fewer times than it is mentioned in different listings. See e.g. N. Jarska, J. Olaszek, Co czytała opozycja..., pp. 159-161.

9 J. Karski, Wielkie mocarstwa a Polska (Od Wersalu do Września), Warszawa: Wydawnictwo Społeczne KOS, 1987. The second part for the years 1939-1945 was published in the same year. 
Dziedzictwo rozczarowania. Polski eksperyment niepodległościowy 1914-1989 (A legacy of disappointment. Polish independence experiment 1914-1989) ${ }^{10}$. These works reveal that the interwar period attracted some interest, referring mostly to the threads concerning the history of communism and Poland's relations with Bolshevik Russia, later the USSR. The Polish-Bolshevik war gained great interest. Besides the aforementioned book of M. Żułowski and the fragment of the one of P. Zaremba ${ }^{11}$ published as a brochure, at least the diaries of Paweł Jasienica ${ }^{12}$ of that time, and the book of Tadeusz Żenczykowski Dwa Komitety 1920, 1944. Polska w planach Włodzimierza Lenina i Józefa Stali$n a^{13}$ [Two Committees 1920, 1944. Poland in the plans of Vladimir Lenin and Joseph Stalin] should be mentioned.

The answer to the question concerning a general evaluation of the $2^{\text {nd }}$ Polish Republic, as presented in the underground publication, is ambiguous. The discussion should start with a dispute which takes place among the activists of the Committee for Social Self-Defence KOR in regard to approaching in 1978 the $60^{\text {th }}$ anniversary of Poland regaining independence in 1918, and developing an adequate statement on this subject. Years after, Jacek Kuron described the discussion within the Committee on the first draft of this document as follows:

Projekt napisali Jerzy Ficowski i Jan Józef Lipski. Kiedy go przedstawili, wybuchła dzika awantura, podzieliśmy się pokoleniowo. Powojenni, wraz z autorami projektu, chcieli wymieniać zasługi, lecz także czarne karty tamtej epoki. Ci, którzy działalność społeczną rozpoczynali przed wojną, odrzucili ten projekt z nieprzepartą energią. «To po co pan profesor zakładał wtedy Ligę Obrony Praw Człowieka i Obywatela?» - pytał [Adam] Michnik Edwarda Lipińskiego. «Bo byłem głupi»-powiedział profesor ${ }^{14}$.

[The draft was written by Jerzy Ficowski and Jan Józef Lipski. A wild storm blew up when they presented it, we were divided among generations. Those post-war, together with the draft authors, wanted to list both merits and black cards of that time. Those who started their social activities before the war rejected the draft energetically. «Why did you establish the League for Human and Citizen Rights Protection that time, Professor?» - [Adam] Michnik asked Edward Lipiński. «Because I was stupid» - said Professor.]

As results from an operational report of the Security Service, eavesdropping regularly KOR meetings at E. Lipiński place, this meeting took place on May 26, 1978. A. Michnik is mentioned also as a co-author of the first draft, along with J. Ficowski and J.J. Lipski. The record of the discussion

10 N. Davies, Dziedzictwo rozczarowania. Polski eksperyment niepodległościowy 1914-1989, Warszawa: Międzyzakładowa Struktura "Solidarności”, 1986.

11 P. Zaremba, Operacja Wista, [s.1.]: SW, 1985; Warszawa: Oficyna LJ, 1989.

12 P. Jasienica, Pamiętnik, Warszawa:, Międzyzakładowa Struktura Solidarności, 1986, p. 43.

13 First edition: T. Żenczykowski: Dwa komitety 1920,1944. Polska w planach Lenina i Stalina. Szkic historyczny, Kraków: [s.n.], 1983 (publisher unknown). The book had 9 underground editions.

14 J. Kuroń, Testament, "Polityka" 22 VI 1996, no 25. 
on the draft is very poor, there is only information that a few participants spoke during the discussion, and Kuron was to offer that the KOR Editing Commission would prepare the following draft, and present it at the meeting at the beginning of July ${ }^{15}$. J.J. Lipski named the same authors of the draft in his book on the history of KOR. He mentioned the discussion and works on the draft: "Perhaps none of KOR statements was the work of the whole Committee to this extent. Many amendments were introduced" 16 . Finally, a compromise was reached and the statement was published.

It underlined a huge work done by the Poles to regain independence, and further to build the state. Particular circumstances were listed: in economy, science, state management. Development of patriotic attitude among young people was perceived as the greatest success of the $2^{\text {nd }} P R$ :

Niepodległa Polska wychowała ideowe pokolenie, świadomych swoich obowiązków obywate-

li. Cały jej dorobek przesądził o postawie narodu w ciężkiej próbie II wojny światowej i do dziś stanowi skarb, dzięki któremu Polska kultura skutecznie opiera się utracie swej tożsamości.

[The independent Poland brought up an ideological generation of citizens aware of their duties. Its achievements determined the nation's attitude in a severe trial of World War II, and until today it has been a treasure thanks to which the Polish culture effectively resists the loss of its identity.]

The main weak points of the $2^{\text {nd }} P R$ were indicated at the same time: "We owe it to the atmosphere of the interwar period, rich in pluralism and responsibility for the state and nation fate, that we can look also critically at shadows and shortcommings of the $2^{\text {nd }}$ PR". The document mentions also unemployment, difficulties in social promotion, lack of access to culture and education for a part of the society, unfinished land reform, the murder of President Gabriel Narutowicz, break of democratic order in 1926, so-called Brest trials and Bereza Kartuska. The KOR activists criticized the situation of national minorities. The document underlines that there were groups that perceived these problems and fought against them in the $2^{\text {nd }} P R$. It was also written that:

Sześćdziesiąta rocznica odzyskania niepodległości jest przede wszystkim świętem tych wszystkich Polaków, którzy walczyli zbrojnie o wolną Polskę, służyli sprawie polskiej rozwijając kulturę i oświatę, krzewiąc wartości demokratyczne, humanistyczne, patriotyczne, którzy tworzyli podstawy społeczne i ekonomiczne życia narodowego. Jest świętem nadziei tych, którzy podtrzymując tradycje narodowe, nawiązując przerwaną ciągłość, broniąc pokrzywdzonych i prześladowanych, walcząc o przyrodzone prawa osoby ludzkiej, budując niezależną kulturę

15 Meldunek operacyjny dotyczacy spotkania działaczy KSS "KOR” w dniu 26 V 1978, [in:] Kryptonim "Gracze”. Stużba Bezpieczeństwa wobec Komitetu Obrony Robotników i Komitetu Samoobrony Spolecznej "KOR" 1976-1981, selection, introduction and compilation by Ł. Kamiński, G. Waligóra, Warszawa 2010, p. 429.

16 J.J. Lipski, KOR. Komitet Obrony Robotników. Komitet Samoobrony Spolecznej, introduction A. Friszke, compilation G. Waligóra, J.T. Lipski, Warszawa 2006, p. 380. 
i naukę, tworząc niezależne instytucje samorządu społecznego - dążą w ten sposób do niepodległej, demokratycznej, sprawiedliwej Polski. Jest świętem całego narodu ${ }^{17}$.

[The $60^{\text {th }}$ anniversary of regaining independence is above all a celebration of all the Poles who fought armed for the free Poland, who served the Polish matter developing culture and education, promoting democratic, humanistic, and patriotic values, who created social and economic of the national life. It is a holiday of hope for those who, maintaining national traditions, and establishing interrupted continuity, defending the victims and persecuted, fighting for the inherent human rights, developing independent culture and science, creating independent institutions of social self-government - thus strive for the independent, democratic, just Poland. It's a celebration of the whole nation.]

This statement reflected best the attitude towards the $2^{\text {nd }} \mathrm{PR}$ of the opposition grown from the KOR circle, in particular, the part gathered around J. Kuron and A. Michnik. "Shadows" of interwar Poland were often mentioned in the journals published by these groups. Michnik, in his text Gnidy $i$ anioty (i.e. the polemics with the famous Traktat o gnidach by Piotr Wierzbicki ${ }^{18}$ ) published in "Zapis" journal, looking for an analogy to the attitudes of intelligentsia of PRL, indicated intellectualists' passivity in the case of the so-called Brest trials before the war ${ }^{19}$. J. Kuroń, Antoni Macierewicz and A. Michnik, leaders of the KOR community, indicated also the mistakes of the $2^{\text {nd }} \mathrm{PR}$ in the politics towards eastern neighbors, in their article Sprawa polska - sprawa rosyjska published in "Głos" journal in $1977^{20}$ :

Rosja panująca nad narodami dzielącymi ją od Polski jest i musi być państwem imperialistycznym godzącym w niepodległość Polski. Nie zawsze jednak uświadamiamy sobie, że to można również odnieść do Polski. Państwo polskie aspirujące do panowania nad Ukrainą, Białorusią i Litwą musi być imperialistyczne. Trudno - co prawda - przypuścić by komukolwiek marzyła się dziś w Polsce taka sytuacja. Lecz jest również prawdą, że w okresie Drugiej Rzeczypospolitej na równi z Rosją Radziecką uczestniczyliśmy w polityce rozbioru Ukrainy, Białorusi i Litwy ${ }^{21}$.

[Russia, reigning over the nations separating it from Poland, is and must be an imperial state endangering Polish independence. However, we are not always aware that the same can be referred to in Poland. The Polish state, aspiring to reign over Ukraine, Belarus and Lithuania, must be imperial as well. Admittedly, it is hard to assume that anyone would dream about such

17 Oświadczenie KSS “KOR” z dnia 11 listopada 1978 r. o niepodległości, [in:] Dokumenty Komitetu Obrony Robotników i Komitetu Samoobrony Społecznej "KOR”, introduction and compilation by A. Jastrzębski, Warszawa 2014, pp. 308-311.

18 P. Wierzbicki, Traktat o gnidach, "Zapis" 1979, no 9.

19 A. Friszke, Czasopisma "drugiego obiegu” [in:] Czasopisma społeczno-kulturalne w okresie PRL, ed. by U. Jakubowska, Warszawa 2011, p. 398; A. Michnik, Gnidy i anioły, "Zapis" 1979, no 9.

20 A. Friszke, Czasopisma "drugiego obiegu"..., p. 404.

21 J. Kuroń, A. Macierewicz, A. Michnik, Sprawa polska - sprawa rosyjska, "Głos" 1977, no 1, p. 12 . 
a situation in Poland today. However, it is also the truth that in the interwar period we participated - equally to Soviet Russia - in the politics of partition of Ukraine, Belarus and Lithuania.]

It is worth noting that the oppositionists, generally very different, remained unanimous in this case. The problem of the $2^{\text {nd }}$ PR eastern borders and the attitude towards national minorities and neighbours emerged in the underground publications among others while discussing the need of regaining independence not only by Poland but Lithuania, Ukraine and Belarus as well. The faith in the ideas of Jagiellonian Poland and eastern ideas of J. Piłsudski and Jerzy Giedroyć dominated. I should mention here (among others) such periodicals as "ABC", "Obóz" and "Nowa Koalicja". Writing on this topic, the authors referred to Piłsudski’s politics, indicating also his mistakes ${ }^{22}$. A nostalgic narration on eastern borders was simultaneously present ${ }^{23}$.

The above-mentioned controversy about the $2^{\text {nd }}$ PR reflects well two pictures of the $2^{\text {nd }}$ People's Republic generally present in underground publications in the years 1976-1989. Two visions existed alongside each another: "a nuanced" and "an idealizing" 24 . For instance, the Movement of Protection of Human and Citizen Right [Ruch Obrony Praw Człowieka i Obywatela, ROPCiO], "competitive" to the KOR community, was more indiscriminate towards the tradition of the $2^{\text {nd }} \mathrm{PR}$. It referred mostly to the evaluation of J. Piłsudski and the whole sanation camp. As far as the KOR community referred positively mostly to the socialist and independence part of the Marshall's biography, the ROPCiO activists and (even more so) the Confederation of Independent Poland (Konferedacja Polski Niepodległej, KPN) accepted as their own the whole Piłsudski's block tradition ${ }^{25}$. It was reflected in the underground publications written by this community. The aforementioned article by J. Kuroń, A. Macierewicz, and A. Michnik, was criticized in "U Progu" periodical" ${ }^{26}$. In turn, Wojciech Ziembiński in 1978 - with no relations to the KOR community, but ROPCiO only in that time - in his text concerning J. Piłsudski in "Opinia" journal wrote quite emotionally on his achievements, depicting the way of experiencing history of at least a part of this community:

22 See J. Skórzyński, Na przekór geopolityce. Europa Środkowo-Wschodnia w myśli politycznej polskiej opozycji demokratycznej 1976-1989, Warszawa 2014.

${ }_{23}$ See W. Parfianowicz-Vertun, Europa Środkowa w tekstach i działaniach. Polskie i czeskie dyskusje, Warszawa 2016, pp. 343-350.

${ }_{24}$ It is difficult to indicate ambiguously critical vision of the $2^{\text {nd }} P R$ in opposition publication - such an image was presented by PRL authorities, mostly in the first decades of communist Poland, it had changed in the following years (which will be discussed below).

25 R. Stobiecki, Józef Pitsudski i jego miejsce w narodowym imaginarium, [in:] Mity i stereotypy w dziejach Polski i Ukrainy w XIX $i$ XX wieku, red. A. Czyżewski, R. Stobiecki, T. Taborek, L. Zaszkilniak, Warszawa-Łódź 2012, pp. 337-338.

26 A. Friszke, Czasopisma "drugiego obiegu”..., p. 410. 
Z trudu i znoju swych żołnierzy Polska powstała, by żyć... Jej Twórca i orężem wytyczy granicę, zwycięży w 1920 r. bolszewicką Rosje i zbuduje podwaliny życia państwowego oraz polskiej racji stanu. Nie przyjmie ofiarowanej mu dwukrotnie godności Prezydenta RP ani nie chce sprawować dyktatury, chociaż w maju 1926 dokona jeszcze jednej rewolucji, umacniając byt państwowy Rzeczypospolitej ${ }^{27}$.

[Poland was created to live by the effort and drudgery of its soldiers... Its Creator will mark the border with weapon, conquer Bolshevik Russia in 1920, and will build the foundations of the state life and the Polish national interest. He will not accept the honor of the President of the Republic of Poland offered him twice - nor does he want to exercise dictatorship, although he will make another revolution in May 1926, strengthening the existence of the People's Republic.] The last words notably could have raised controversies among a part of opposition communities. Their author relativized the suppression of democracy by Piłsudski. The others, non-historians in particular, would be outraged by Tadeusz Łepkowski words, who compared repressiveness (its existence, but not a scale) of the $2^{\text {nd }}$ PR and PRL. This historian, related to the opposition, wrote in the essay Myśli o historii Polski i Polaków published in 1983 by CDN:

Rządzący nami w XX wieku wciąż powtarzają, że wiedzą, iż Polakami nie można kierować siłą, że trzeba się liczyć z ich zdaniem. Wciąż też powtarzają ze złością, że naród się nie sprawdza, a mimo tu usiłują rządzić bez narodu. Było tak po uchwaleniu autorytarnej konstytucji 1935 roku, jest tak w PRL w całej rozciągłości i brutalności, zwłaszcza po grudniu 1981 roku. I tu drobna uwaga: idealizacja relacji między państwem, społeczeństwem i jednostkami w II Rzeczypospolitej, zrozumiała dziś, jest w istocie szkodliwa, bo sprzeczna z historyczną prawdą. Jest jednak jeden ważki argument za podkreślaniem jakościowej różnicy w tym zakresie między RP i PRL. Pierwsza była niepodległa, druga nie. W pierwszej rządy (nawet po 1935 roku) miały, choćby ograniczony, mandat społeczeństwa, w drugiej tego mandatu nie posiadają wcale ${ }^{28}$.

[Those who have been governing us in the $20^{\text {th }}$ century repeat constantly that they know that the Poles cannot be governed by force, that their opinion should be valued. They still repeat angrily that the nation is not working, and yet they are trying to rule without the nation. It was like that after they passed an authoritarian constitution in the year 1935, it is like that in PRL in all its extent and brutality, in particular after December 1981. A small comment here: the idealisation of relation between the state, the society and individuals in the $2^{\text {nd }} \mathrm{PR}$, understood nowadays, is actually harmful, as contrary to historical truth. However, there is one important argument for the underlying qualitative difference between the $2^{\text {nd }} \mathrm{PR}$ and PRL in this range. The former was independent, the latter not. Governments in the former (even after 1935) had at least limited social mandate, while the latter has not this mandate at all.] A feature characteristic for the critic of the $2^{\text {nd }} P R$ in underground publications is clearly seen here, which is emphasizing that its faults were smaller than those of Poland ruled by the communists.

27 W. Ziembinski, Pierwszy żotnierz Rzeczpospolitej, "Opinia” 1 XII 1977, no 8, p. 3.

28 T. Łepkowski, Myśli o historii Polski i Polaków, Warszawa: CDN, 1983, p.13. 
However, despite the critical attitude of the opposition towards J. Piłsudski's politics (in particular after 1926) in general, its image as presented in the total output of independent publishing was positive. Niezależna Oficyna Wydawnicza (Independent Publishing House) published very quickly (in 1978) his famous Bibuta, which was reissued four times more in underground publishing ${ }^{29}$. Publication of this famous brochure was important, as the very existence of independent publishing movement kept it current - J. Piłsudski wrote there about developing and disseminating "Robotnik" (Workman) periodical and its role in the organisation of secret structures of Polska Partia Socjalistyczna (Polish Socialist Party, PPS). At this point, it is impossible not to pay attention to the reference to that periodical established by J. Piłsudski in the title of "Robotnik" journal published by KOR (and developed by the editorial team managed by Helena Łuczywo and Jan Lityński, close to J. Kuroń and A. Michnik) ${ }^{30}$. The figure of Piłsudski was permanently present in independent publications. In total 26 editions of books and brochures of his authorship were published underground ${ }^{31}$. There are also many works dedicated to him written by other authors. Most of the texts about J. Piłsudski were positive. Biographical books concerning J. Piłsudski were also published underground. Andrzej Romanowski wrote about him in "Arka" in Kraków ${ }^{32}$. Piłsudski was also often presented in calendars and post stamps published in underground ${ }^{33}$. The "Kurs" journal (Łódź-Warszawa) published a selection of poems concerning Piłsudski in 1984, written by Maria Pawlikowska-Jasnorzewska, Emil Zegadłowicz, Jan Lechoń and Kazimierz Wierzyński ${ }^{34}$.

The "Piłsudski Józef" entry in Niezależna encyklopedia powszechna (1988) published in the series "Zeszyty Edukacji Narodowej" by Prawy Margines publishing house, related to "Solidarność Walcząca" is focused mostly on his role in Poland regaining independence, and protection of its borders after the World War I. The following was written about his participation in a domestic politics after 1926:

W maju 1926 r. przeprowadził P. zbrojny zamach stanu na tzw. trzeci gabinet W. Witosa, posługując się swoimi zwolennikami w armii oraz popularnością społeczną, szczególnie

29 J. Piłsudski, Bibuła (Warszawa: Niezależna Oficyna Wydawnicza, 1978; Warszawa: Wydawnictwo Nieobecnych, 1982; Warszawa: Wydawnictwo Pokolenie, 1986; Wrocław: NZS, 1988; Kraków: Panaceum, 1988).

30 See J. Olaszek, Rewolucja powielaczy. Niezależny ruch wydawniczy w Polsce 1976-1989, Warszawa 2015, pp. 71-73.

31 N. Jarska, J. Olaszek, Co czytata opozycja ..., p. 153.

32 A. Friszke, Czasopisma “drugiego obiegu”..., pp. 457-458.

33 S. Plate, Duże przestania w malym formacie. Znaczki poczty niezależnej w latach osiemdziesiatych w Polsce, [in:] Czas bibuly. Mechanizmy - ludzie - idee. Vol. 2, ed. by R. Wróblewski, Wrocław 2013, p. 160.

34 D. Dabert, Między wizja a spetnieniem. Profile ideowe i artystyczne czasopism literackich w drugim obiegu wydawniczym 1982-1989, Poznań 2014, p. 179. 
w kręgach lewicowych. Padały krwawe ofiary; prezydent S. Wojciechowski skapitulował i złożył urząd. Sejm, którego demokratyczna wola została złamana., zaakceptował ex post zamach majowy, wybierając P. na prezydenta. Było to pierwsze z cyklu «nielogicznych zdarzeń», które towarzyszyły już P. do samej śmierci. Odrzucił on wybór; formalnie do końca pozostał tylko Generalnym Inspektorem Sił Zbrojnych oraz Ministrem Spraw Wojskowych, jeżeli nie liczyć epizodycznego kierowania gabinetem; faktycznie był pierwsza osobą w państwie, jakby dyktatorem, czyniąc jednak ze swej władzy użytek dość umiarkowany i w ściśle ograniczonych granicach. W polityce wewnętrznej zabezpieczał P. pozycję własną oraz obozu rządzącego, który stopniowo się przy nim formował z kadry legionowo-peowiackiej, lecz z udziałem bardzo różnych elementów. Przeciwne mu siły polityczne zwalczał na ogół środkami politycznymi; nie usunął ani nie zwasalizował Sejmu, choć ten próbował utrzymać swoją pozycję; nie usiłował zniszczyć partii, chociaż w «partyjniactwie» upatrywał główne źródło plag polskich, a partie stopniowo uformowały rozległy front opozycyjny; do kroków drastycznych, bezprawnych, posuwał się wyjątkowo, jak np. walka z blokiem «centro-lewu» (więzienie i proces brzeski), czy pacyfikacje burzących się wsi ukraińskich. Zmierzał do «sanacji», czyli uzdrowienia polskiego życia publicznego, ku czemu widział drogę w legalnym uchwaleniu nowej konstytucji, dającej wyjątkową pozycję prezydentowi i zwiększającej uprawnienia wykonawcze rządu. Konstytucja taka została uchwalona w kwietniu 1935, a P. zatwierdził jej tekst już na łożu śmierci. Jest to ustawa kontrowersyjna do dziś, z przewagą opinii jednak krytycznych; dawne, niewątpliwe słabości systemu władzy zastąpiono w niej słabościami nowymi - przede wszystkim neutralizacją inicjatywy oraz kontroli społecznej. Szczególną uwagę poświęcał P. wojsku; utrzymywał je w sile i na poziomie aż do granic możliwości ekonomicznych kraju; nie eksperymentował z nowościami technicznymi i operacyjnymi, lecz akcentował walory ludzkie i siły moralne; kładł nacisk na funkcje wychowawcze armii, na jej rolę integrującą Polaków w imię nadrzędnego interesu narodowego, a wbrew podziałom politycznym i warstwowym. Nie leżała w sferze oddziaływań P. kultura, Kościoły ani życie gospodarczo-społeczne. Realizował do końca życia centrowy kurs politycznym, a przeciwników najbardziej nieprzejednanych miał przede wszystkim na wyraźnej prawicy oraz lewicy ${ }^{35}$.

[In May 1926 P[iłsudski] carried out an armed coup d'état overthrowing the so-called third cabinet of W. Witos, using his supporters in the army and social popularity, in leftist circles in particular. There were blood victims; President S. Wojciechowski capitulated and resigned his office. The Parliament, a democratic will of which was broken, ex-post accepted the May coup d'état, electing P. as president. This was the first of the cycle of «illogical events» which followed P. until his death. He rejected the election; formally he was just the First Marshal of Poland and the Minister of Military Affairs if to ignore an episode of leading a cabinet. Actually, he was the first person in the state, a kind of a dictator, however using moderately his power, in strictly defined limits. He protected the position of his own and the governing camp

35 K.P., Pitsudski Józef, [in:] Niezależna Encyklopedia Powszechna. Vol. 2: A-Z, Warszawa: Prawy Margines, 1988, pp. 95-59. 
in the internal politics, which had been forming gradually from among the legions and the Polish Military Organisation, with the participation of very diversified elements. He coped against his political opponents mostly with political means; he neither closed nor madethe Parliament his vassal, although the latter tried to keep its position. He did not strive to destroy the party, although he perceived «party politics» as the main source of Polish plagues, and the parties had gradually formed a wide opposition front. He exceptionally used extraordinary measures, like for instance a fight with «a center-leftist» block (a prison and the Brest trials), or pacification of raging Ukrainian villages. He aimed at «sanation»(restoring health), i.e. recovery of the Polish public life, which he considered achievable by a legally passed new constitution, warranting an exceptional position of a president, and increasing executive rights of a government. Such a constitution was passed on April 1935, and P. accepted its text on his deathbed. This constitution has been controversial until nowadays, with critical opinions prevailing. Old, undoubted weaknesses of the governing system were replaced there by new ones - mostly neutralisation of social initiative and control. P. put specific attention to the army. He kept it strong and at a level up to the economic limits of the country. He did not experiment with technological nor operational news but focused on human values and moral strengths. He underlined the educational functions of the army, its role in integrating the Poles in the name of a superior national interest, despite political or class divisions. He had not influenced culture, churches, nor economic and social life. He pursued a central political course until his death, having the most implacable opponents on the clear right or left.]

On the one hand, undemocratic activities of Piłsudski are indicated in the entry above, on the other however - the author tried to express his understanding towards the figure he described and to prove that he strived to realize a mild politics, as compared to other dictators. This was a dispute with the vision of the $2^{\text {nd }}$ PR system after 1926 as presented in the official version of history, in particular in the first decades of the communists governance in Poland. There were many similar voices. For instance Marian Piłka, an oppositionist related to ROPCiO and Young Poland Movement (Ruch Młodej Polski, RMP) in the brochure Deformacje w wykładzie historii w podręcznikach dla szkół średnich published in 1984 wrote about one of school textbooks:

Nieprawdziwie przedstawione są rządy sanacji, które niejednokrotnie określane są jako faszyzujące. Brak prezentowanych innych modeli poza modelem państwa socjalistycznego i faszystowskiego sprawia, iż ustrój II Rzeczyspospolitej wtłaczany jest do tego drugiego modelu ${ }^{36}$. [The sanation governance, often referred to as fascist, is misrepresented. No other models are presented except the model of a socialist and fascist state, therefore the $2^{\text {nd }}$ PR system is forced into the other one.]

36 M. Piłka, Deformacje w wykładzie historii w podręcznikach dla szkół średnich, Warszawa: Wydawnictwo MKK, 1984, p. 154. The brochure was a reprint of the article published before in "Zeszyty Historyczne" in Paris. This text was also reprinted in a brochure in the same year by "Promieniści" publishing house in Kraków. 
The essay of A. Michnik Cienie zapomnianych przodków is one of the most important underground texts concerning J. Piłsudski, due to its meritorious value and the author himself. It was originally published in "Kultura" in Paris, 1975 , then it was reissued underground 7 times in the country ${ }^{37}$. It is worth mentioning that two years earlier his essay was awarded the prize "Józef Piłsudski in the eyes of young generations of the Poles" organised by the Józef Piłsudski Institute in London. The chief opposition activist and a long-term political prisoner wrote there about the $2^{\text {nd }} P R$, placing J. Piłsudski against R. Dmowski and two traditions related to them. The first - as for the author - was related to freedom and independence, while the other to compliance and xenopho$\mathrm{bia}^{38}$. He perceived the former as the one worth continuing in a natural way. In Michnik's text we read:

Stałością ludzkiego umysłu jest szukanie analogii. W spotkaniu z totalitarną rzeczywistością jesteśmy bezradni, bezsilni, szukamy jakichś sytuacji, które wskazywać by mogły, jak inni, w innym czasie zachowywali się, stając wobec dylematów podobnych do naszych. I wtedy właśnie - w 1968 roku - przeczytałem relację o spotkaniu Dmowski-Witte w 1905 roku i wtedy wyłoniły się z cienia twarze aktorów tamtych wydarzeń, ludzi, którym dane było w jednym życiu doznać najczarniejszej beznadziei i ujrzeć biało-czerwony sztandar na Zamku Królewskim w Warszawie. Niepodległość stworzyła nową perspektywę do myślenia o orientacjach polityki polskiej w ciągu ubiegłych lat dwudziestu. Jaśniej było widać, które działania tę niepodległość przybliżały, a które oddalały, jaśniejszą stała się także istotna sporu o kształt niepodległości. Co mnie uderzyło w rozmowie Dmowskiego z Wittem? Oto polski polityk komunikuje rosyjskiemu premierowi, że ruchy rewolucyjne w Polsce są dziełem przybyłych z Rosji Żydów i że jednym remedium na ten stan rzeczy jest przek zanie władzy w Warszawie Polakom, którzy sami ukrócą działanie socjalistycznych bojówek. Na czele tych bojówek stał, lżony i poniewierany przez endeckich żurnalistów, Józef Piłsudski, najwyraźniej powolne narzędzie w rękach rosyjsko-żydowskich agitatorów, bez których - jak dowodziły endeckie gazety - Polakom nigdy nie przyszło do głowy walczyć o sprawy niepodległości i społecznej reformy.

[Searching for analogy is a permanence of human mind. Meeting a totalitarian reality, we are helpless, powerless, we search for any situation indicating how the others behaved in other times, facing similar dilemmas. And that time - in 1968 - I read the relation about Dmowski-Witte meeting in 1905, and faces of the actors of those events came from the shadows, people who experienced the darkest hopelessness and saw the white and red banner on the Royal Castle in Warsaw in one life. Independence gave a new perspective for thinking about

37 A. Michnik, Cienie zapomnianych przodków (Warszawa: Niezależna Oficyna Wydawnicza, 1978; Kraków: TKN, 1978; Kraków: by the effort of the students of Towarzystwo Kursów Naukowych in Kraków, 1979, Łódź: Międzyzakładowa Oficyna Wydawnicza "Mowa", 1981; Poznań: Samodzielna Oficyna Literacka TKN, 1983; Kraków: "Bez cięć", 1985; Kraków: "Nowa", 1985).

38 A. Friszke, Czasopisma "drugiego obiegu”..., p. 420. 
orientations of Polish politics during last twenty years. It was more clearly visible which activities brought the independence closer, and which removed it, as well as the essence of a dispute about independence shape. What did hit me in the Dmowski-Witte conversation? There is the Polish politician who communicates the Russian prime minister that revolutionary movements in Poland are organised by the Jews coming from Russia, and the only remedy for this state of the matter is passing the governing in Warsaw to the Poles, who would tackle activities of socialist militants themselves. Józef Piłsudski was a leader of these militants, insulted and abused by national-democratic journalists, actually a submissive tool in the hands of Russian-Jewish agitators, without which - as proved by national-democratic newspapers - the Poles would never thing about fight for independence and social reform.] J. Piłsudski’s attitude, according to A. Michnik, standed out against the background of mostly passive Polish society, for which defence of Polishness was actually limited to some traditional rituals:

Piłsudski wyłonił się z nocy, która zapadła w Królestwie Polskim po klęsce powstania styczniowego. Najpierw ważną wydała mi się być analiza tej «nocy», przyjrzenie się z bliska, jak ludzie wtedy myśleli i postępowali. Milczenie, wewnętrzna emigracja - takie było najczęściej rozwiązanie. Rozumiały i zasadny bezpośrednio po klęsce, w czas jakiś później wybór ten nabrał charakteru dwuznacznego. Obrona języka ojczystego, obyczaju i tradycji w zaciszu domowego ogniska, obrona substancji narodowej w czterech ścianach własnego domu i podczas przygodnych kontaktów z sąsiadami czy kuzynami, wytwarzała osobliwy rodzaj patriotyzmu i szczególny typ patrioty. Patriota taki manifestował swą polskość spożywaniem tradycyjnego barszczu i śpiewaniem okolicznościowych kolęd wtedy, kiedy inni już spiskowali. On nie spiskował. Dla niego spiski były dziełem Moskali i nieodpowiedzialnych demagogów, którzy narażali naród na kolejne hekatomby represji. Obrona «substancji narodowej» poprzez redukcję jej do sfery języka i obyczaju prowadziła do zapoznania istotny konfliktu Polaków z carską Rosją. Istotą działania rosyjskiej szkoły była nie tylko rusyfikacja językowa, ale także - może głównie - «rusyfikacja» duchowa, przyuczenie do życia w kłamstwie i niewoli. Obrońcy «substancji narodowej» bronili polskiej formy, gubiąc jej istotną zawartość. Dziś powiedzieliśmy, że byli narodowi w formie i rosyjscy w treści.

[Piłsudski came out from the night which fell in the Kingdom of Poland after collapse of the January Uprising. First, I found important analysis of this «night», looking closer how people thought and acted that time. Silence, internal emigration - these were the most popular solutions. This choice - understandable and reasonable just after the collapse, some time later became ambiguous. Defence of national language, habits and traditions in the comfort of one's home, defence of national substance in one's own home and during casual contacts with neighbours or nephews, created patriotism of a specific kind, and a patriot alike. Such a patriot manifested his/her Polishness eating traditional borsch and singing occasional carols, while the others just conspired. He did not. Conspiracy was for him the work of Russians and irresponsible demagogues, who endangered the nation with the following hecatombs of repressions. Defence of «national substance» with its reduction to language and 
habit led to underestimation of the core of conflict between the Poles and the tsarist Russia. The essence of a Russian school activity was not only russification of language, but also or mostly - spiritual «russification», adaptation to life in falsehood and slavery. Defenders of «national substance» actually defended Polish form, but lost its essential contents. Today we would say that they were national in form, but Russian in contents.]

This was the attitude of R. Dmowski, according to the oppositionist:

Nie wiem, czy potrafię zrozumieć dylematy tamtych ludzi, ale złość Piłsudskiego z powodu nazywania każdej podłości działaniem realistycznym jest mi jakoś bliska. Któż w końcu okazał się realistą? Czy optujący za współpracą z carską Rosja Roman Dmowski? Ten najlogiczniejszy z polskich myślicieli politycznych, zręczny gracz, chłodny realista, nie dostrzegł przecież i nie zrozumiał dynamiki procesów społecznych w rosyjskim imperium. Akceptując - «realistycznie» - obecność rosyjskich pułków w Warszawie, skoncentrował się na wychowaniu «nowoczesnego Polaka». «Nowoczesny Polak» miał słuchać rosyjskiego generał-gubernatora, rozbijać żydowskie sklepy i czekać na zmianę koniunktury międzynarodowej. Wtedy zjednoczone zostaną, być może, pod berłem cara wszystkie ziemie polskie, to znaczy prócz Warszawy także Poznań i Kraków znajda się w zasięgu kozackiej nahajki. Z rozmaitymi «socjałami» - dostrzegał tu Dmowski na ogół żydowską rękę - winien «nowoczesny Polak» podjąć pryncypialną polemikę. I podjął tę polemikę w 1905 roku - za pomocą bojówek endeckich uzbrojonych w kastety i rewolwery, które pomagały rosyjskim żołdakom wyplenić rewolucyjną zarazę. Piłsudski nie był taki nowoczesny. Skierowywanie namiętności narodowych w koryto prorosyjskiego w skutkach antysemityzmu potępiał, widząc w tym - słusznie - naśladowanie rosyjskiej «czarnej sotni». Zastępowanie walki z caratem rozbijaniem żydowskich sklepów uważał za podłość i głupotę: współpracę za stójkowymi w łamaniu robotniczych strajków nazywał po imieniu - zdradą ${ }^{39}$.

[I do not know if I can understand dilemmas of those people, however Piłsudski's anger at calling each wickedness a realistic activity is somehow close to me. Who appeared to be a realist eventually? Was it Roman Dmowski, opting for cooperation with the tsarist Russia? He was the most logical person among the Polish political thinkers, a skilful player, a cold realist, yet he did not notice nor understand dynamics of social processes in the Russian Empire. «Realistically» accepting presence of Russian regiments in Warsaw, he focused on education of «a modern Pole». The latter was to listen to a Russian General Governor, to destroy Jewish shops, and to wait for change of international situation. Then, perhaps, all Polish lands will be united under the Tsar's sceptre, that is, apart from Warsaw, also Poznań and Kraków will be within the reach of the Cossacks knout. The «modern Pole» should start principled polemic with different «socialists»- Dmowski considered there mostly a Jewish hand. And he started this polemic in 1905 - with national-democratic militants armed with brass knuckles and guns, which helped Russian soldiers to eradicate this revolutionary plague. Piłsudski was not that modern. He condemned directing national

39 Cited after the edition: A. Michnik, Cienie zapomnianych przodków (fragmenty), "Poglądy. Pismo społeczno-polityczne" 1985, no 5. 
The $2^{\text {nd }}$ Polish Republic in underground publications in the Polish People's Republic

passions into pro-Russian anti-Semitism, perceiving that - justly - imitation of the Russian «Black Hundreds». Destruction of Jewish shops instead of fight against tsarism he considered as wickedness and stupidity: cooperation with policemen in breaking workmen strikes he called by its name - a betrayal.]

It is worth noting here that in the KOR statement at the $60^{\text {th }}$ anniversary of independence, widely discussed above, R. Dmowski was not mentioned. Although the KOR community did not refuse him some merits in regaining independence, it was seriously critical towards him and his tradition, mostly due to national democracy anti-Semitism.

What A. Michnik wrote about R. Dmowski was unacceptable for the Gdańsk RMP community, which tried to reinterpret national-democratic tradition, rejecting its anti-Semitism, but deriving other values from it. Their leader Aleksander Hall started a polemic with A. Michnik text in the independent journal "Bratniak", published by this community. The oppositionist underlined that a dispute with the author of Cienie zapomnianych przodków is not easy:

Michnik pisze sugestywnie, z wielką pasją. Trudno uwolnić się od jego wpływu i zdobyć się na sprzeciw wobec przedstawionej przez niego wizji przeszłości i sposobu odczytywania teraźniejszości. Dla Michnika punkt wyjścia do rozważań o Piłsudskim stanowi otaczająca nas rzeczywistość.

[Michnik writes suggestively, with great passion. It is hard to relieve of his influence and find opposition to his vision of the past, and his way of interpreting the present. For Michnik the reality around as is a starting point for deliberations about Piłsudski.]

A. Hall argued with A. Michnik in the theses concerning either history or the present ${ }^{40}$. He defended R. Dmowski against accusations of compliance and primitive nationalism, he also argued strongly with A. Michnik thesis concerning national-democratic tradition related to "March'68" 41 . R. Dmowski's thought was important for RMP not only as a part of history but also as the concepts where answers to more present questions can be found. RMP-related Młoda Polska publishing house from Gdańsk, published underground in 1981 for the first time Myśli nowoczesnego Polaka. A. Hall in the introduction to this brochure explained the decisions on its publishing as follows:

Pierwszy powód jest oczywisty. «Myśli nowoczesnego Polaka» należą do najważniejszych polskich książek ideowo-politycznych. Wpłynęły nie tylko w istotny sposób na kształtowanie się ideologii i programu Narodowej Demokracji, lecz także oddziaływały w znacznym stopniu na postawy i poglądy bardzo wielu Polaków nie identyfikujących się z obozem Romana Dmowskiego [...]. Książka Dmowskiego wywołała też szereg sprzeciwów i polemik. Słowem, stała się naprawdę wielkim wydarzeniem z polskim życiu intelektualnym tamtych czasów. Już sam ten fakt wystarczająco uzasadnia wydanie tej książki przez wydawnictwo

40 A. Hall, Polemika z "Cieniami zapomnianych przodków”, "Bratniak" 1978, no 6-7, pp. 13-17.

41 A. Friszke, Czasopisma "drugiego obiegu”..., p. 420. 
formułujące w swych celach także poszerzenie wiedzy o historii polskiej myśli. Jednak nie tylko to zadecydowało o wznowieniu przez nas «Myśli nowoczesnego Polaka». Książka ta stanowi istotny element intelektualnego i ideowego dorobku myśliciela i polityka, którego wkład do polskiej myśli nie ma bynajmniej jedynie historycznego, czy antykwarycznego znaczenia. Można z niego w dalszym ciągu czerpać i uczyć się. Za centralną wartość swej politycznej filozofii Roman Dmowski uważał naród. Zmieniały się na przestrzeni lat jego poglądy na relacje zachodzące między narodami oraz jednostką i narodem, zawsze jednak naród pozostawał w centrum jego myśli. Nie akceptował i nie rozumiał człowieka poza wspólnotą narodową.

[The first reason is obvious. «Myśli nowoczesnego Polaka» belongs to the most important Polish ideological and political books. It significantly influenced not only the development of the ideology and program of National Democracy but also the attitudes and opinions of many Poles not identifying themselves with Roman Dmowski's camp. [...] The book by Dmowski triggered many objections and polemics. Let's say, it became a really big event in the Polish intellectual life of that time. This fact as such is a sufficient reason for publishing this book by the publishing house offering development of knowledge about the history of Polish thought among its goals. However, not only that decided about the reissue of «Myśli nowoczesnego Polaka». The book is an essential element of the intellectual and ideological output of the politician, whose contribution to the Polish thought has not only historical or antiquarian significance. It can still be a learning source. Roman Dmowski perceived a nation as a central value of his political philosophy. His views on relations among nations and between an individual and a nation have been evolving in time, however, a nation has always been in the very center of his thought. He neither accepted nor understood a man outside a national community.]

Hall perceived the development of ideological foundations for the modern Polish national movement as the main merit of Dmowski. He also put attention to critical evaluation of the so-called Polish national character and the faults of the nation in this brochure. RMP leader focused also on these elements of Dmowski's thought which are hardly acceptable: belief in the primacy of strength over moral reasons and approval for victories based on violence. He tried to explain that:

Należy jednak pamiętać, że był to okres, w którym pod wpływem idei pozytywistycznych, na których wychowała się ówczesna polska inteligencja, niezwykle popularne było przenoszenie darwinowskiej teorii biologicznej w świat społeczny i polityczny. Była to epoka, w której zaborcy niemieccy i rosyjscy bezwzględnie walczyli z polskością. Jednym z najważniejszych, o ile nie najważniejszym zadaniem książki Dmowskiego, było uświadomienie Polakom całego dramatyzmu sytuacji, w jakiej się znajdują, brutalne ukazanie im zagrożeń narodowego bytu, porwanie ich do walki, w której mogli liczyć tylko na własne siły. Stale pamiętać musimy, że w przypadku Polski zasada egoizmu narodowego, sformułowana została w bardzo poważnym stopniu z przyczyn taktycznych - mając służyć mobilizacji sił narodowych strony słabszej, znajdującej się w konflikcie z interesami wielkich europejskich 
The $2^{\text {nd }}$ Polish Republic in underground publications in the Polish People's Republic

mocarstw. Dmowski nie tylko pragnął opisać polską rzeczywistość, ale zamierzał zastosować «kurację wstrząsową». Niewątpliwie w znacznym stopniu udało mu się ten cel osiągnąć.

[However, it should be remembered that this was a period when transmission of the Darwin biological theory into social and political life was extremely popular, due to the influence of positivist ideas in which the Polish intelligentsia of that time was brought up. This was the era when German and Russian invaders ruthlessly fought against Polish identity One of the most important tasks of Dmowski's book was to make the Poles aware of the whole drama of the situation, to show them brutally threats of national existence, to drive them into the fight where they could count only on themselves. We have to remember constantly, that as for Poland the rule of national egoism was mostly formulated due to tactical reasons - to serve for mobilization of national forces of a weaker party, being in a conflict of interests with great European powers. Dmowski not only wanted to describe the Polish reality but also to apply a «shock therapy». Undoubtedly, he achieved this goal to a large extent.]

Hall underlined that Dmowski withdrew from a national egoism later. In the thought of National Democracy leader he saw a message relevant, in his opinion, at the beginning of the 80 s. of the $20^{\text {th }}$ century:

W dobie współczesnej zadaniem idei narodowej musi być dążenie do przybliżenia stanu, w którym rzeczywistością stałoby się współdziałanie narodów, ich harmonijna współpraca w oparciu o wspólny ideał cywilizacyjnym przezwyciężanie wrogości i uprzedzeń. Musi ona zakładać, że pewnego dnia ludzkość może stać się rodziną narodów, a świat - właśnie dzięki temu - stać się bardziej ludzki ${ }^{42}$.

[Nowadays the national idea should aim at the state when the interaction of the nations, their harmonious cooperation based on common civilizational ideal of overcoming hostility and prejudices would be a reality. It must assume that humanity can once become a family of nations, and the world - can become more human, thanks to that.]

The publishers added Dmowski's biographical entry to the reissued book, highlighting his merits and avoiding the problem of anti-Semitism, just like Hall in his text.

The book of Wojciech Wasiutyński Czwarte pokolenie. Szkice z dziejów nacjonalizmu polskiego ${ }^{43}$ published in 1987 can be mentioned as another one devoted to this figure, as well as the publicist book of P. Wierzbicki Myśli staroświeckiego Polaka, referring to Dmowski. The latter author cut off the national-democratic anti-Semitism, he wrote about it mostly in terms of a political mistake, avoiding its moral evaluation ${ }^{44} .28$ editions of books and brochures

42 A. Hall, [Stowo wstępne], [in:] R. Dmowski Myśli nowoczesnego Polaka, Gdańsk: Młoda Polska, 1981.

43 W. Wasiutyński, Czwarte pokolenie. Szkice z dziejów nacjonalizmu polskiego, Warszawa: "Periculum", 1987.

44 P. Wierzbicki, Myśli staroświeckiego Polaka (Warszawa: Głos, 1985; Warszawa: Baza, 1986; Warszawa: Bis, 1986; Warszawa "Periculum", 1986; Warszawa: no publisher 1986; Wrocław: Wektory, 1986; Gdańsk: Biblioteka Polityki Polskiej, 1986; Warszawa: Głos, 1987). 
with Dmowski's works were published underground ${ }^{45}$. It is worth noting that Unia Nowoczesnego Humanizmu (Modern Humanism Union) belonged to their publishers, although a part of its other publications were unambiguously anti-Semitic.

The community of "Res Publika" journal was equally critical towards Piłsudski and national-democratic traditions. Its chief editor Marcin Król perceived referring to such old traditions and perceiving them as a key to modern times as anachronistic. He considered that only critical deliberation on history could lead to the development of valuable, opposition political thought. He did not want to choose between "Piłsudski's coffin" and "Dmowski's coffin", which - according to J. Giedroyć - ruled the Poles' minds. Text of Barbara Toruńczyk Dlaczego endecja?, where she criticized affirmative referring to this tradition ${ }^{46}$, was published in this journal next to the sketch of Wojciech Karpiński Cien Pitsudskiego, who wrote that Piłsudski's thought caused lack ofacceptance of the collapse of the January Uprising, what was valuable in the time of fights for independence, but not for governing the $2^{\text {nd }}$ People's Republic ${ }^{47}$.

The aforementioned thread of anti-Semitism in the $2^{\text {nd }} P R$ was often discussed in underground publications, mostly in relation to the national-democratic context. For instance, a piece of Nierzeczywistość by Kazimierz Brandys was published in the first issue of "Zapis", where the author mentioned beating him by national-democratic militant at the university ${ }^{48}$. In turn, a warning against accusing anti-Semitist attitudes to all academic corporations active before the war (most of them were national-democratic, but not all) can be found in underground published Wspomnienia of P. Jasienica:

W spopularyzowanym dziś pojęciu każdy korporant musiał koniecznie uczestniczyć w burdach antysemickich, bijąc pałką nie tylko Żydów, lecz i Żydówki także, wyrzucać z wózków niemowlęta. Członkowie polonii nie mieszali się w te procedery ${ }^{49}$.

[In the currently popular concept each student association member had to participate in anti-Semitic brawls, beating either Jewish men or women with a baton, throwing away babies from strollers. Members of Polonia did not take part in these actions.]

The Polish Socialist Party tradition was quite strongly represented in independent publishing, also from this period when it was definitely not along the way with J. Piłsudski. The tradition of this party was close to the KOR

$45 \quad$ N. Jarska, J. Olaszek, Co czytała opozycja..., p. 153.

46 BT [B. Toruńczyk], Dlaczego endecja?, "Res Publika" 1979, no 2, pp. 58-68.

47 WK [Wojciech Karpiński], Cień Pitsudskiego, "Res Publika" 1979, no 2, pp. 69-78.

48 A. Friszke, Czasopisma "drugiego obiegu..., p. 394.

49 P. Jasienica, Pamiętnik..., s. 43. Previously this fragment was published in the Warsaw journal "Wezwanie". It was also published in the same year by one of underground publishing houses in Kraków. 
community, which was expressed either in "Głos" or "Krytyka" journals ${ }^{50}$. The Polish Socialist Party reactivated in 1987 relied upon this tradition in a natural way in publications of related journals and publishing houses. Recalling this tradition, its appropriation by the communists was mentioned ${ }^{51}$. The heritage of Polskie Stronnictwo Ludowe (Polish People's Party, PSL) and the people's movement, in general, was present in independent publication, mostly those somehow related to independent peasants movement and "Solidarność" (Solidarity) of the farmers. However, this interest concerned mostly post-war history of this movement, when it was the main oppositionist against the communists.

The pre-war history of the latter also met a bit of popularity, to mention renowned Mój wiek by Aleksander Wat, with several underground editions ${ }^{52}$. In underground publications, they argued with the official vision of the history of Communist Party of Poland (Komunistyczna Partia Polski, KPP). It is worth quoting again, for example, M. Piłka's brochure, who wrote about one of the official textbooks:

Dzieje II Rzeczypospolitej rozpatrywane są niemal wyłącznie z punktu widzenia ruchu komunistycznego, któremu poświęcono znaczną ilość miejsca. Jego rola jest karykaturalnie wyolbrzymiona. Już same tytuły rozdziałów i podrozdziałów np. «Wzrost nastrojów rewolucyjnych na ziemiach polskich»; «Rozwój wpływów rewolucyjnych w Polsce»; «KPP na czele walki o antyfaszystowski front ludowy» sugerują, iż był to bardzo ważny czynnik kształtujący oblicze Polski okresu międzywojennego. To błędne mniemanie podbudowane jest obszerną prezentacją wybranych elementów z działalności ruchu komunistycznego (w sumie 13 stron). To obszerne omówienie dalekie jest jednak zarówno od prezentacji całości najważniejszych cech tego nurtu, jak też od prawdy. Brak w opisie zwłaszcza stosunku ruchu komunistycznego do kwestii niepodległości, granic Polski i to nie tylko wschodnich, ale i zachodnich oraz charakteru «rozwiązania» KPP. Natomiast stwierdzenie, iż komuniści stali «na czele» czegokolwiek poza działalnością agenturalną, jest po prostu nieprawdziwe ${ }^{53}$.

[The history of the $2^{\text {nd }} \mathrm{PR}$ is discussed almost exclusively from the communist movement point of view, which received the most attention. Its role is grotesquely exaggerated. Just the titles of chapters and sections, like «Increase of revolutionary moods within Polish territories»; «Development of revolutionary influences in Poland»; «KPP as a leader of the fight for anti-fascist people's front» suggest that it was a very important factor influencing Poland's image in the interwar period. This misguided belief is based on an extensive presentation

50 A. Friszke, Czasopisma “drugiego obiegu”..., p. 407.

51 See L. Mielnicki [Edmund Reński], Skradzione sztandary PPS, Warszawa: Wydawnictwo Społeczne KOS, 1987.

${ }_{52}$ First underground edition: A. Wat, Mój wiek, Warszawa: Niezależna Oficyna Wydawnicza, 1980.

53 M. Piłka, Deformacje w wykładzie historii..., p. 15. 
of selected elements from the communist movement activity (13 pages in total). However, such an extensive description is far from either presentation of all important features of this movement, or the truth. The description misses, in particular, an attitude of communist movement towards the issue of independence, Polish borders (not only eastern, but western as well), and the character of KPP «solution». In turn, the statement that the communists were «at the forefront» of anything but agents' activities is simply false.]

Concluding, it should be stated that social and economic issues were poorly represented in underground publications. However, it does not mean that it did not appear, at least in economic publications. Also, opposition historians were writing about that, like aforementioned T. Łepkowski, who analyzed problems of workmen, peasants, and intelligentsia ${ }^{54}$. When considering the reasons of presenting or not different issues related to the $2^{\text {nd }} \mathrm{PR}$ in underground publications it should be noted that independent publishing movement had not an ambition to replace official press and book circulation, but only to assure the readers' access to those authors, titles and topics, which would not be available in another way, or were officially presented in a false way. Therefore mostly political threads were discussed most often.

The image of the $2^{\text {nd }} \mathrm{PR}$ in underground publications certainly had a significant "bent". Since "dark" aspects of this period of the history of Poland were mostly presented officially, it was done conversely in underground publications. Partial idealization of the $2^{\text {nd }}$ PR and some paradoxes are related to that, for instance - that the democratic movement, activists of which were on political trials and went to prisons, took on its banners Piłsudski, who was responsible for the Brest trials and Bereza Kartuska. Simultaneously, the opposition activity was not a good time for nuances. Piłsudski fascinated as "a father" of independence and raised sympathy as a person criticized by the communists. It referred mostly to some young oppositionists, for example, those related to KPN ${ }^{55}$. However, it did not mean that all opposition communities were uncritical towards the interwar period. Authors publishing underground were divided in this regard. A part of them stated that lights of that time should be mostly presented, while others tried to consider also the shadows. Both of them treated the $2^{\text {nd }} P R$ as something incomparably better than PRL.

Translated by Matgorzata Kisilowska

${ }^{54}$ T. Łepkowski, Myśli o historii Polski..., pp. 27-28, 33.

55 See e.g. G. Wołk, Ostatnie pokolenie piłsudczyków? Młodzieżowe organizacje afiliowane przy warszawskiej Konfederacji Polski Niepodległej, [in:] Życie na przekór. Antysystemowa kontestacja młodzieży w ostatniej dekadzie PRL (1980-1989) - nowe tropy i pytania badawcze, ed. by B. Noszczak, Warszawa 2016, pp. 303-334. 


\section{References}

BT [Barbara Toruńczyk], Dlaczego endecja?, "Res Publika” 1979, no 2, pp. 58-68.

Dabert D., Między wizją a spetnieniem. Profile ideowe i artystyczne czasopism literackich $w$ drugim obiegu wydawniczym 1982-1989, Poznań 2014.

Davies N., Dziedzictwo rozczarowania. Polski eksperyment niepodległościowy 19141989, Warszawa: Międzyzakładowa Struktura "Solidarności”, 1986.

Dokumenty Komitetu Obrony Robotników i Komitetu Samoobrony Społecznej “KOR”, introduction and compilation A. Jastrzębski, Warszawa 2014.

Friszke A., Czasopisma "drugiego obiegu", [in:] Czasopisma społeczno-kulturalne w okresie PRL, ed. by U. Jakubowska, Warszawa 2011, pp. 383-462.

Hall A., Polemika z "Cieniami zapomnianych przodków”, "Bratniak” 1978, no 6-7, pp. 13-17.

Hall A., [Słowo wstęne], [in:] R. Dmowski Myśli nowoczesnego Polaka, Gdańsk: Młoda Polska, 1981.

Klincz J. [Joanna Szczęsna], Rajd po skrzynkach, "Tygodnik Mazowsze” 29 VII 1987, no 218 , p. $1,3$.

Jarska N., Olaszek J., Co czytała opozycja? Książki drugiego obiegu jako wyraz tożsamości politycznej, ideowej i kulturowej opozycji w PRL (1976-1989), [in:] Drugi obieg w PRL na tle samizdatu w państwach bloku sowieckiego po 1956 roku, ed. by P. Gasztold-Seń, N. Jarska and J. Olaszek, Warszawa 2016, pp. 145-162.

Jasienica P., Pamiętnik, Warszawa: Międzyzakładowa Struktura Solidarności, 1986.

K.P., Piłsudski Józef, [in:] Niezależna Encyklopedia Powszechna. Vol. 2: A-Z, Warszawa: Prawy Margines, 1988, pp. 55-59.

Karski J., Wielkie mocarstwa a Polska (Od Wersalu do Września), Warszawa: Wydawnictwo Społeczne KOS, 1987.

Kryptonim “Gracze”. Stużba Bezpieczeństwa wobec Komitetu Obrony Robotników i Komitetu Samoobrony Społecznej “KOR” 1976-1981, selection, introduction and compilation Ł. Kamiński, G. Waligóra, Warszawa 2010.

Kuroń J., Macierewicz A., Michnik A., Sprawa polska - sprawa rosyjska, “Głos” 1977, no 1 , pp. 11-14.

Kuroń J., Testament, "Polityka" 22 VI 1996, no 25, pp. 69-72.

Łepkowski T., Myśli o historii Polski i Polaków, Warszawa: CDN, 1983.

Lipski J.J., KOR. Komitet Obrony Robotników. Komitet Samoobrony Społecznej, introduction A. Friszke, compiled by G. Waligóra, J.T. Lipski, Warszawa 2006.

Michnik A., Cienie zapomnianych przodków (fragmenty), "Poglądy. Pismo społeczno-polityczne" 1985, no 5.

Michnik A., Cienie zapomnianych przodków, Warszawa: Niezależna Oficyna Wydawnicza, 1978.

Michnik A., Gnidy i anioły, "Zapis" 1979, no 9.

Mielnicki L. [Edmund Reński], Skradzione sztandary PPS, Warszawa: Wydawnictwo Społeczne KOS, 1987. 
Niezależna encyklopedia powszechna. T. 2: A-Z, Warszawa: Prawy Margines, 1988.

Olaszek J., Rewolucja powielaczy. Niezależny ruch wydawniczy w Polsce 1976-1989, Warszawa 2015.

Paczkowski A., Przeszłość jako obszar starcia o legitymizację-manewry obronne PZPR $w$ okresie finalnego kryzysu systemu, [in:] Meandry legitymizacji. Studia i analizy, ed. by I. Pańków, Warszawa 2011.

Parfianowicz-Vertun W., Europa Środkowa w tekstach i działaniach. Polskie i czeskie dyskusje, Warszawa 2016.

Piłka M., Deformacje w wykładzie historii w podręcznikach dla szkót średnich, Warszawa: Wydawnictwo MKK, 1984

Piłsudski J., Bibuła, Warszawa: Niezależna Oficyna Wydawnicza, 1978.

Plate S., Duże przestania $w$ matym formacie. Znaczki poczty niezależnej $w$ latach osiemdziesiatych w Polsce, [in:] Czas bibuty. Mechanizmy - ludzie - idee. Vol. 2, ed. by R. Wróblewski, Wrocław 2013, pp. 147-163.

Skórzyński J., Na przekór geopolityce. Europa Środkowo-Wschodnia w myśli politycznej polskiej opozycji demokratycznej 1976-1989, Warszawa 2014.

Stobiecki R., Józef Pitsudski i jego miejsce w narodowym imaginarium, [in:] Mity i stereotypy w dziejach Polski i Ukrainy w XIX i XX wieku, ed. by A. Czyżewski, R. Stobiecki, T. Taborek, L. Zaszkilniak, Warszawa-Łódź 2012.

Wasiutyński W., Czwarte pokolenie. Szkice z dziejów nacjonalizmu polskiego, Warszawa: "Periculum", 1987.

Wat A., Mój wiek, Warszawa: Niezależna Oficyna Wydawnicza, 1980.

Wierzbicki P., Myśli staroświeckiego Polaka, Warszawa: Głos, 1985.

WK [Wojciech Karpiński], Cień Piłsudskiego, ”Res Publika” 1979, no 2, pp. 69-78.

Zaremba M., Komunizm, legitymizacja, nacjonalizm. Nacjonalistyczna legitymizacja władzy komunistycznej w Polsce, Warszawa 2005.

Zaremba P., Operacja Wisła, [s.1.]: SW, 1985.

Żenczykowski T., Dwa komitety 1920,1944. Polska w planach Lenina i Stalina. Szkic historyczny, Kraków: [s.n.], 1983.

Żeromski S., Na probostwie w Wyszkowie, foreword J.J. Lipski, Warszawa: Niezależna Oficyna Wydawnicza, 1978.

Ziembiński W., Pierwszy żołnierz Rzeczpospolitej, “Opinia” 1 XII 1977, no 8, p. 3.

Zułowski M., [Ryszard Zieliński] Wojna z Rosja o niepodległość 1918-1920, Warszawa: Wydawnictwo Polskie, 1978.

Życie na przekór. Antysystemowa kontestacja młodzieży w ostatniej dekadzie PRL (19801989) - nowe tropy i pytania badawcze, ed. by B. Noszczak, Warszawa 2016. 